\title{
THE TEMPORAL EVOLUTION OF NORTH AMERICAN KIMBERLITES
}

\author{
Larry M. Heaman ${ }^{1}$ and Bruce A. Kjarsgaard ${ }^{2}$ \\ ${ }^{1}$ Dept. of Earth \& Atmospheric Sciences, University of Alberta, Edmonton, T6G 2E3; \\ ${ }^{2}$ Geological Survey of Canada, Ottawa K1A OE8
}

\section{Introduction}

The origin of kimberlite magmatism remains one of the more controversial topics in petrology. Many of the models postulated for kimberlite genesis imply a quite specific temporal-spatial relationship and predict that the timing of kimberlite magmatism is linked to some large-scale tectonic process; such as subduction of oceanic lithosphere (e.g. McCandless, 1999), rifting of continents (e.g. Phillips et al., 1998) or impact of mantle plumes (e.g. Heaman and Kjarsgaard, 2000). In order to better constrain the origin and cause of kimberlite magmatism it is important to have a solid understanding of certain aspects of kimberlite genesis such as: 1) what is the likely mantle source material capable of producing an ultrabasic magma with the requisite mineralogy and geochemistry of a kimberlite, 2) what are the constraints on the depth of melting in the mantle required for kimberlite genesis, and 3) what are the possible triggers responsible for mantle melting to produce kimberlite? To address the latter question in detail, it is imperative to understand both the local and global timing/distribution of kimberlite magmatism and whether there is any relationship between kimberlite magma generation and contemporaneous tectonic processes. Large-scale patterns of kimberlite emplacement (e.g. craton-wide) could help identify subcontinental mantle processes that are linked to kimberlite formation. In this presentation we compile more than one hundred robust radiometric age determinations for kimberlites in North America and speculate on the cause(s) of the observed temporalspatial patterns of kimberlite emplacement.

\section{Distribution of Kimberlites}

Prior to 1988 , the total number of known kimberlites in North America was approximately 50 . The discovery of significant diamond-bearing kimberlite in North America ( 1990) has fuelled an intensive search for kimberlites and related rocks, especially in Canada. The number of new kimberlite discoveries continues to grow annually and the total number of known kimberlites at the time of writing exceeds approximately 540 Kjarsgaard and Levinson, 2002). The majority of kimberlites in North America occur in fields or clusters that span the entire continent. Some of the larger and better established kimberlite fields are shown in Figure 1 and include; Attawapiskat (Ontario),
Buffalo Head Hills (Alberta), Finger Lakes (New York), Fort à la Corne (Saskatchewan), Kirkland Lake (Ontario/Québec), Lac de Gras (N.W.T.), Somerset Island (Nunavut), State Line (Colorado/Wyoming), and Timiskaming (Ontario/ Québec). As exploration continues, a number of exciting new fields of kimberlite (and related rock types) have been discovered including; Northern Slave (Nunavut), Otish (Québec), Torngat (Labrador), Victoria Island (Nunavut), and Wawa (Ontario).

There is abundant evidence that the control on final kimberlite emplacement in many of the North American fields is related to major crustal structures or the intersection of structures. For example, many of the kimberlite fields are related to crustal scale faults and structural zones (Sage, 1996; Moorhead et al., 2000); Attawapiskat field (Winisk River structural zone), Kirkland Lake field (Porcupine-Destor and Cadillac faults), Otish field (Temiscamie-Corvette structural zone) and western Slave kimberlites (Beniah Lake fault). To a first approximation at a continental scale, there is no obvious large-scale pattern to the distribution of kimberlites within North America. Although most are located within stable Archean cratons, some fields occur in regions dominated by Proterozoic and younger crust (e.g. Buffalo Head Hills, Missouri Breaks).

\section{Timing of Kimberlite Magmatism}

North American kimberlites have been emplaced over a period of approximately one billion years. The oldest known kimberlites (senso stricto) are Mesoproterozoic and examples include the $1.1 \mathrm{Ga}$ Bachelor Lake and Kyle Lake kimberlites (Québec and Ontario). There are possibly much older kimberlite (or kimberlite-like) intrusions in North America, such as the Archean Wawa dykes, but the exact timing and origin of these unusual rocks is still much debated. The youngest kimberlites are Tertiary in age and occur in western North America (e.g. Lac de Gras, N.W.T. and Missouri Breaks diatremes, Montana). In this paper we review a compilation of robust kimberlite emplacement age dates for more than 100 kimberlite intrusions in North America. The possible origins of these kimberlites are discussed in the light of spatial-temporal patterns of emplacement. 
Phanerozoic kimberlite magmatism in North America can be broadly subdivided into four geographic regions, based on patterns of emplacement (Figure 1). These include; 1) a NE Eocambrian Labrador Sea province (east coast of Labrador and eastern Québec), 2) an eastern dominantly Jurassic (180-140 Ma) province, including many of the kimberlites in Ontario, western Québec, New York, Pennsylvania (Heaman and Kjarsgaard, 2000 and references therein), 3) a Cretaceous (103-94 Ma) central province or corridor (Nunavut, Saskatchewan and central U.S.A.), which includes the 103-94 Ma Somerset Island and 103-95 Ma Fort à la Corne fields (Heaman and Kjarsgaard, 2002), and 4) a western mixed (Eocene-Eocambrian) province, which includes amongst others, kimberlite fields in Alberta, Northwest Territories, Nunavut, and Wyoming/ Colorado. The western mixed age province contains two Type 3 kimberlite provinces (as defined by Mitchell, 1986) where multiple kimberlite fields with a variety of emplacement ages occur in a small geographic area.

\section{Eocambrian Labrador Sea Province}

North American Eocambrian and Cambrian kimberlite magmatism is widespread and is currently recognized in the Wyoming Craton (e.g. 615-600 Ma; Chicken Park, George Creek and possibly Green Mountain kimberlites), Slave Craton (e.g. 542-523 Ma; Snap and Kennady Lake kimberlites) and in the Labrador Sea Province (e.g. 580-550 Ma; Beaver Lake kimberlite and Abloviak ultrabasic lamprophyre dykes). The majority of kimberlites and related rocks dated so far in much of Québec and Labrador are Eocambrian in age so we designate this region as the Eocambrian Labrador Sea Province. This Eocambrian period of kimberlite magmatism pre-dates estimates for the timing of Taconic subduction (e.g. 550-450 Ma; Waldron et al., 1998) but overlaps with the timing of Eocambrian rifting along the northeastern margin of Laurentia at $615 \mathrm{Ma}$ (e.g. Kamo et al., 1989). We propose that the majority of Eocambrian/Cambrian kimberlites and related magmatism that occurs in eastern North America and in western Greenland (Larsen and Rex, 1992) is associated with rifting and opening of the Iapetus Ocean. At present there is insufficient geochronology to evaluate whether there is any temporal-spatial pattern of Eocambrian kimberlite magmatism that may coincide with the existence of mantle plume hotspot tracks attendant with this continental rifting. The origin of Eocambrian and Cambrian kimberlites elsewhere in North America is unclear. It is curious that this period of kimberlite magmatism worldwide is generally richly diamondiferous (e.g. $520 \mathrm{Ma}$ Venetia kimberlite in southern Africa; Allsopp and Smith, 2002)

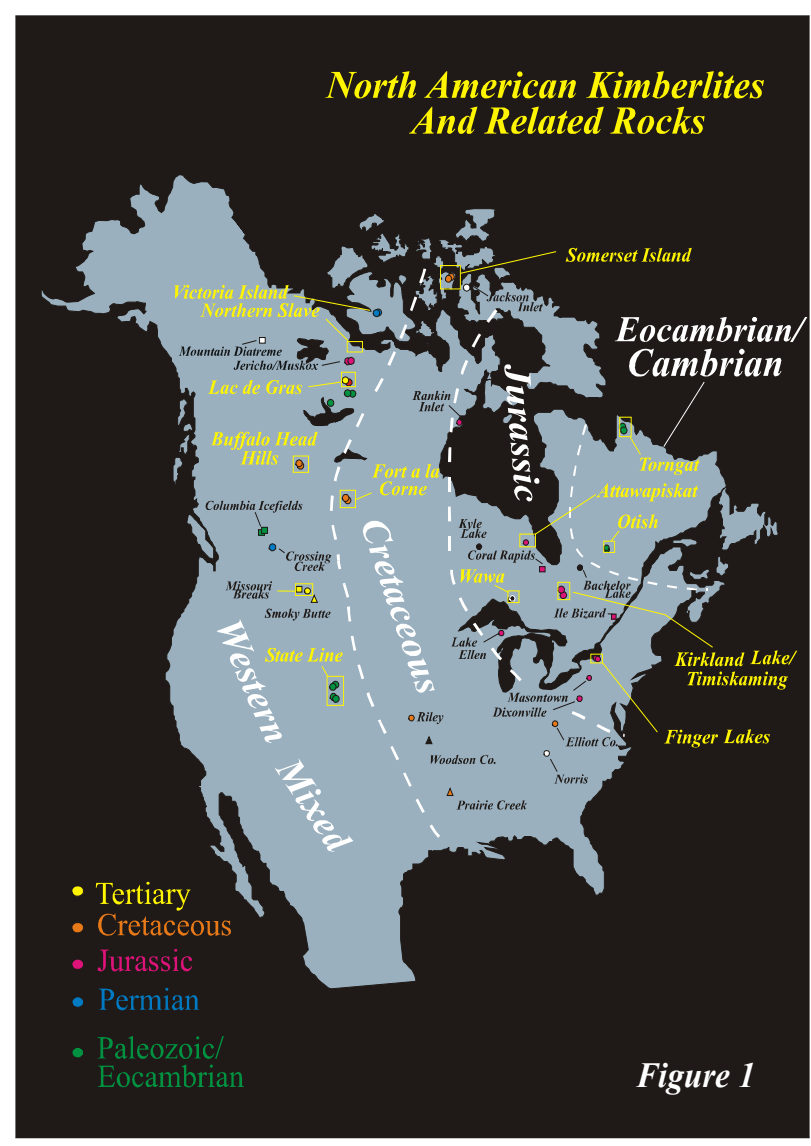

\section{Eastern Jurassic Province}

From a geochronology perspective, the eastern Jurassic province (Figure 1) has been studied in most detail (e.g. Heaman and Kjarsgaard, 2000 and references therein). A NE-SW corridor of kimberlite magmatism can be traced for more than $2000 \mathrm{~km}$ from as far northwest as Rankin Inlet (196 Ma) through to the Attawapiskat (180 and $155 \mathrm{Ma})$, Kirkland Lake (157-152 Ma), and Timiskaming (155-134 Ma) fields. This corridor of kimberlite magmatism generally follows a pattern of southeast younging that is geographically coincident with independent estimates for the timing and location of the continental extension of the Great Meteor hotspot track (Heaman and Kjarsgaard, 2000). In such cases, it is possible that significant mantle plume activity accompanies continental rifting events that are driven by upwelling mantle asthenosphere (Weinstein and Olson, 1989). In the case of the Rankin to Kirkland Lake kimberlite corridor, the magmatism is linked to opening of the North Atlantic Ocean, initiated at about 
$200 \mathrm{Ma}$. There is also Jurassic kimberlite magmatism in the Slave craton (e.g. the 173 Ma Jericho kimberlite, Heaman et al., 2002) that appears to have an origin unrelated to the eastern North America Jurassic kimberlite magmatism.

\section{Central Cretaceous Corridor}

All Eocene and the majority of Cretaceous kimberlite magmatism occur in central and western North America. A notable exception to the dominantly western Cretaceous kimberlite fields is the $\sim 90 \mathrm{Ma}$ Elliott County kimberlite in Kentucky (Heaman, 1989). The Cretaceous corridor of kimberlite magmatism defined on Figure 1 includes the 103-94 Ma Somerset Island field in Nunavut, 103-95 Ma Fort à la Corne field in Saskatchewan and some central U.S.A. occurrences such as the Riley County kimberlites (e.g. 95 $\pm 6 \mathrm{Ma}$ Winkler kimberlite; Brookins and Naeser, 1971). Several Cretaceous kimberlite clusters occur in the Western Mixed Domain (Figure 1; Table 3) and include the 88-86 Ma Buffalo Head Hills field and 78$70 \mathrm{Ma}$ Birch Mountains cluster in Alberta and some kimberlites in the Lac de Gras field, such as the 74-70 Ma Hardy Lake cluster. Eocene kimberlite magmatism is prevalent in the Lac de Gras field, N.W.T. and in the Missouri Breaks region of Montana (e.g. $48 \mathrm{Ma}$ Williams kimberlite; Marvin et al., 1980).

There are some noticeable temporal-spatial patterns of Cenozoic/Mesozoic kimberlite magmatism in western North America. The most notable is the $\sim \mathrm{N}-\mathrm{S}$ trending Cretaceous corridor (Figure 1), where kimberlites in a number of fields extending from Somerset Island to Kansas have emplacement ages in the narrow time range between 103-94 Ma. Equally striking is the corridor-like pattern of Maastrichtian/Campanian kimberlites that occur in the Lac de Gras field (e.g. 73$71 \mathrm{Ma}$ Hardy Lake cluster) and in Alberta (e.g. 78-70 Ma Birch Mountains cluster). Although it is more difficult to define a corridor of Eocene kimberlite magmatism, the 56-48 Ma Lac de Gras and much of the Eocene Missouri Breaks magmatism does occur west of most Cretaceous kimberlite occurrences (i.e. west of the thin white dashed line in Figure 1).

The origin of continental scale corridors of kimberlite magmatism emplaced over a relatively short interval (10-20 Ma) is unclear. Such corridors of kimberlite magmatism that generally mirror the margin of the continent and young towards a convergent margin could represent an emplacement pattern consistent with the subduction hypothesis (e.g. McCandless, 1999). and interestingly coincides with a major flare-up of Eocene volcanic activity in the Cordillera (Armstrong, 1988).

Another possible explanation for the observed pattern of Cretaceous/Tertiary kimberlite magmatism in western North America is that during this time the margin was subjected to large-scale extension. We note that there is abundant evidence for Cordilleran Eocene extension and a major flare-up of Eocene bimodal volcanic activity (Armstrong, 1988) that is contemporaneous with Eocene kimberlite magmatism in western North America. Various tectonic processes other than subduction (e.g. lithospheric decompression, asthenospheric upwelling, back-arc spreading) have been proposed to explain this Cordilleran Eocene magmatism. Therefore, the origin of the Eocene kimberlite magmatism in the Missouri Breaks and Lac de Gras regions could be linked to either Eocene crustal extension caused by changes in geometry to KulaFarallon plate subduction or upwelling of asthenosphere.

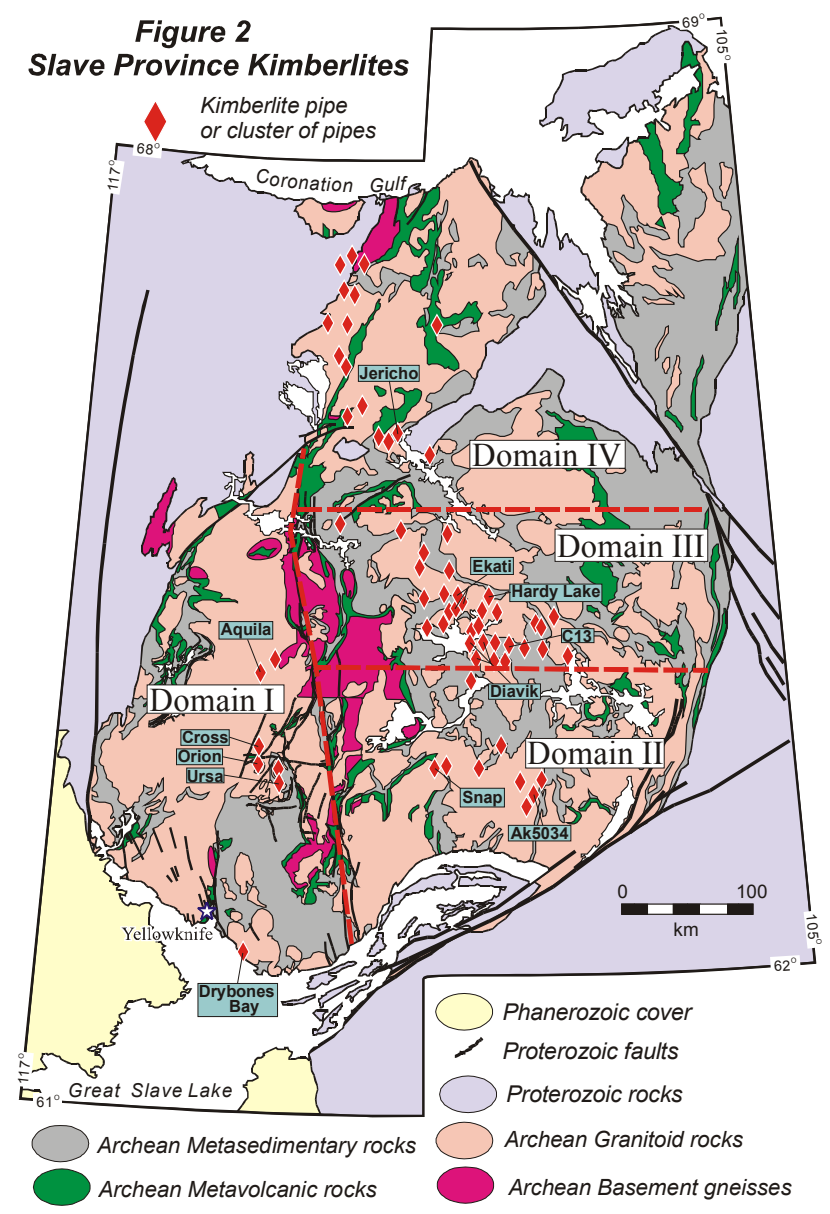




\section{Western Mixed Province}

In the Slave craton alone, several ages of kimberlite emplacement have been reported (Heaman et al., 2003). Based on a relatively small number of kimberlite age determinations, the Slave craton contains kimberlite fields of Eocene, Cretaceous, Jurassic, Permian, SiluroOrdovician and Cambrian age; some of these occur in relatively close spatial proximity (Davis and Kjarsgaard, 1997; Heaman et al., 2003). Likewise, kimberlites in the Wyoming craton have a large range in emplacement age (Heaman et al., 2003) from Devonian (386-400 Ma; Iron Mountain, Estes Park) to Eocambrian (e.g. 615-600 Ma; Chicken Park, George Creek and possibly Green Mountain).

Taking a closer look at the kimberlite emplacement pattern within the Slave craton, at the present time there are age dates available for approximately 25 kimberlites, which represents less than $10 \%$ of the more than 326 known kimberlite occurrences. Kimberlite magmatism in the Slave craton spans a period of time nearly 500 m.y. in duration from the Cambrian $542 \mathrm{Ma}$ Kennady Lake AK5034 pipe (Heaman et al., 2003) to the Eocene (47.5-56.0 Ma) pipes in the Lac de Gras field (Davis and Kjarsgaard, 1997; Graham et al., 1999). The large numbers of kimberlite clusters and fields in the Slave craton, many within $150 \mathrm{~km}$ of the Lac de Gras area (excluding the northern Slave kimberlites), have discrete emplacement ages spanning most of the Phanerozoic. In this respect, the Slave craton is identical to the highly diamondiferous Type 3 kimberlite provinces of southern Africa and Yakutia.

The Slave Province kimberlites depicted in Figure 2 demonstrate a distinct spatial correlation with certain periods of kimberlite magmatism. On this basis the central Slave craton has been crudely subdivided into four kimberlite age segments or domains (heavy dashed lines in Figure 2): I - a southwestern Slave domain characterized by Siluro-Ordovician kimberlite magmatism (435 Ma Orion, 441 Ma Drybones Bay, 450 Ma Cross and 459 Ursa kimberlites), II - a southeastern Slave domain characterized by Cambrian kimberlite magmatism (542 Ma AK5034 kimberlite and 523-535 Ma Snap Lake dyke; Agashev et al., 2001; Heaman et al., 2003), III - a central Slave domain dominated by Cretaceous and Eocene kimberlite magmatism (48-74 Ma kimberlites centered around Lac de Gras) and, IV a northern mixed domain consisting of at least two known periods of magmatism: Jurassic kimberlites in the Contwoyto field (e.g. $\sim 173$ Ma Jericho pipe; Heaman et al., 2002) and a Permian kimberlite field ( 256-286 Ma; Kahlert, pers. comm.) located much further north on Victoria Island (Figure 1). Permian and Triassic kimberlite magmatism is generally rare in North America but one other example does exist in southeastern British Columbia; the $241 \mathrm{Ma}$ Cross Creek kimberlite (Smith et al., 1988).

At present there is no obvious explanation for this apparent domain pattern of kimberlite emplacement. The inferred N-S trending boundary separating the southwestern Slave Siluro-Ordovician domain from the other domains is approximately coincident with the exposed eastern margin of the Anton terrane (or Central Slave Basement Complex); the geologically ancient (pre-2.8 Ga) part of the Slave craton. Interestingly, these Siluro-Ordovician kimberlites (Drybones Bay, Ursa, Orion, Cross and possibly Aquila) align along a N-S linear trend, which parallels the Beniah Lake fault a major intra-Slave N-S crustal-scale fault system. Despite the fact that there may be a coincidence in the position of a major Slave Province structure and the eastern boundary of the Siluro-Ordovician Domain I kimberlite domain, there are no obvious geological controls that might coincide with the other kimberlite age domains.

The Eocene to Cretaceous kimberlite magmatism in the central Slave Domain III is focused within a $50-\mathrm{km}^{2}$ area in the Lac de Gras region. The fact that only the Eocene kimberlites in the Lac de Gras field appear to be of economic significance (i.e. all the dated pipes at Ekati and Diavik), even though both Eocene and Cretaceous kimberlite pipes occur in close proximity (e.g. the $55 \mathrm{Ma}$ highly diamondiferous A154 and $74 \mathrm{Ma}$ C13 pipes occur within less than $5 \mathrm{~km}$ ) at the present erosional level, indicates that other factors must control the distribution of diamonds in this kimberlite field.

\section{Conclusions}

An evaluation of robust radiometric dates for more than one hundred North American kimberlites indicates that there are distinct temporal-spatial patterns of emplacement that are not consistent with a single origin for kimberlite magmatism. In general, North American kimberlite magmatism can be subdivided into four geographic regions based on age and pattern of emplacement: 1) NE Eocambrian/Cambrian Labrador Sea province, 2) eastern Jurassic (180-140 Ma) province, 3) central Cretaceous (103-94 Ma) province or corridor and 4) western mixed (Eocene to Eocambrian) province. The origin of many kimberlites in North America remains unknown, however a strong case can be put forward that the kimberlites and related rocks in the Eocambrian/Cambrian Labrador Sea 
province are related to the opening of the Iapetus Ocean at $615 \mathrm{Ma}$, the eastern NE-trending Jurassic kimberlite corridor formed along the continental extension of the Great Meteor mantle plume hotspot track initiated during the opening of the North Atlantic ocean and the Cretaceous/Tertiary corridors of kimberlite magmatism in western North America could have been triggered by heating of the subcontinental mantle during large-scale interaction with upwelling asthenosphere. In addition, it is possible that the Mesoproterozoic $(\sim 1.1 \mathrm{Ga})$ kimberlites in the Lake Superior region are linked to heating of the Superior Province subcontinental mantle during an aborted attempt at intracontinental rifting (i.e. 1109-1086 Ma Mid Continent rift).

\section{References}

Agashev, A.M., Pokhilenko, N.P., McDonald, J.A., Takazawa, E., Vavilov, M.A., Sobolev, N.V., and Watanabe, T., 2001. A unique kimberlite-carbonatite primary association in the Snap Lake dyke system, Slave craton: evidence from geochemical and isotopic studies. In: The Slave-Kaapvaal Workshop, program with abstracts, 42-44.

Allsopp, H.L. and Smith, C.B., 2002. The emplacement age and geochemical character of the Venetia kimberlite bodies, Limpopo belt, Northern Transvaal, South African Journal of Geology (in press).

Armstrong, R.L., 1988. Mesozoic and early Cenozoic magmatic evolution of the Canadian Cordillera. In: Processes in continental lithospheric deformation. Eds. Clark, S.P., Burchfiel, B.C., and Suppe, J. Geological Society of America Special Paper 218, 55-91.

Aravanis, T., 1999. Legend property assessment report, Birch Mountains area, Alberta. Alberta Energy and Utilities Board/Alberta Geological Survey Assessment File Report 20000003, 23p.

Brookins, D.G., and Naeser, C.W., 1971. Age of emplacement of Riley County, Kansas, kimberlites and possible minimum age for the Dakota sandstone, Geological Society of America Bulletin 82, 1723 1726.

Davis, W.D., and Kjarsgaard, B.A., 1997. A Rb-Sr isochron age for a kimberlite from the recently discovered Lac de Gras field, Slave Province, Northwest Territories, Canada. Journal of Geology 105, 503-509.

Heaman, L.M., 1989. The nature of the subcontinental mantle from $\mathrm{Sr}-\mathrm{Nd}-\mathrm{Pb}$ isotopic studies on kimberlitic perovskite. Earth and Planetary Science Letters 92, 323-334.

Heaman, L.M., Kjarsgaard, B.A., Creaser, R.A., Cookenboo, H.O. and Kretschmar, U., 1997. Multiple episodes of kimberlite magmatism in the Slave Province, North America. Lithoprobe Workshop Report 56, 14-17.

Heaman, L.M., and Kjarsgaard, B.A., 2000. Timing of eastern North American kimberlite magmatism: continental extension of the Great Meteor hotspot track? Earth and Planetary Science Letters 178, 253-268.

Heaman, L.M., and Kjarsgaard, B.A., 2002. A Cretaceous corridor of kimberlite magmatism: $\mathrm{U}-\mathrm{Pb}$ results from the Fort à la Corne field, central Saskatchewan. Geological Association of Canada/Mineralogical Association of Canada Meeting in Saskatoon, Saskatchewan, 47.

Heaman, L.M., Creaser, R.A., and Cookenboo, H.O., 2002. Extreme high-field-strength element enrichment in Jericho eclogite xenoliths: A cryptic record of Paleoproterozoic subduction, partial melting and metasomatism beneath the Slave craton, Canada. Geology 30, 507-510.

Heaman, L.M., Kjarsgaard, B.A. and Creaser, R.A. 2003. The Timing of Kimberlite Magmatism in North America: Implications for Global Kimberlite Genesis and Diamond Exploration. Lithos (in press).

Kamo, S.L., Gower, C.F., and Krogh, T.E., 1989. Birthdate for the Iapetus Ocean? A precise U-Pb zircon and baddeleyite age for the Long Range dikes, southeast Labrador. Geology 17, 602-605.

Kjarsgaard, B.A., and Levinson, A.A., 2002. Diamonds in Canada. Gems and Gemology 38, 208-239.

Larsen, L.M., and Rex, D.C., 1992. A review of the $2500 \mathrm{Ma}$ span of alkaline-ultramafic, potassic and carbonatitic magmatism in West Greenland. Lithos 28, 367-402.

Marvin, R.F., Hearn, B.C.Jr., Mehnert, H.H., Naeser, C.W., Zartman, R.E., and Lindsay, D.A., 1980. Late Cretaceous-Paleocene-Eocene igneous activity in north central Montana. Isochron West 29, 5-25.

McCandless, T.E. 1999. Kimberlites: Mantle expressions of deep-seated subduction. In: Gurney, J.J., Gurney, J.L., Pacsoe, M.D. and Richardson, S.H. (eds). Proceedings of the 7 th International Kimberlite Conference 2, 545-549.

Mitchell, R.H., 1986. Kimberlites, Plenum Press, New York, $442 \mathrm{pp}$.

Moorhead, J., Perreault, S., Berclaz, A., Sharma, K.N.M, Beaumier, M. and Cadiux, A.-M.., 2000. Kimberlites and diamonds in northern Québec. .

Phillips, D., Machin, K.J., Kiviets, G.B., Fourie, L.F., Roberts, M.A., and Skinner, E.M.W., 1998. A petrographic and ${ }^{40} \mathrm{Ar} /{ }^{39} \mathrm{Ar}$ geochronological study of the Voorspoed kimberlite, South Africa: Implications for the origin of Group II kimberlite magmatism. South African Journal of Geology 101, 299-306.

Sage, R.P., 1996. Kimberlites of the Lake Timiskaming Structural Zone. Ontario Geological Survey, Open File $5937,435 \mathrm{p}$.

Smith, C.B., Colgan, E.A., Hawthorne, J.B., and Hutchinson, G., 1988. Emplacement age of the Cross kimberlite, southesastern British Columbia, by the $\mathrm{Rb}-\mathrm{Sr}$ phlogopite method. Canadian Journal of Earth Sciences 25, 790-793.

Waldron, J.W.F., Anderson, S.D., Cawood, P.A., Goodwin, L.B., Hall, J., Jamieson, R.A., Palmer, S.E., Stockmal, G.S., and Williams, P.F., 1998. Evolution of the Appalachian Laurentian margin: Lithoprobe results in western Newfoundland. Canadian Journal of Earth Sciences 35, 1271-1287.

Weinstein, S.A., and Olson, P.L., 1989. The proximity of hotspots to convergent and divergen plate boundaries. Geophysical Research Letters 16, 433436. 